\title{
Acquisition procedures, processing methodologies and preliminary results of magnetic and ROV data collected during the TOMO-ETNA experiment
}

\author{
Danilo Cavallaro ${ }^{1,2,{ }^{\star}}$, Luca Cocchi ${ }^{3}$, Mauro Coltelli ${ }^{1}$, Filippo Muccini ${ }^{3}$, \\ Cosmo Carmisciano $^{3}$, Marco Firetto Carlino ${ }^{1}$, Jesús M. Ibáñez $z^{1,4}$, Domenico Patanè ${ }^{1}$, \\ Marco Filippone ${ }^{5}$, Erika Buttaro ${ }^{6}$ \\ ${ }^{1}$ Istituto Nazionale di Geofisica e Vulcanologia, Sezione di Catania, Osservatorio Etneo, Catania, Italy \\ ${ }^{2}$ Università di Catania, Dipartimento di Scienze Biologiche, Geologiche e Ambientali, Catania, Italy \\ ${ }^{3}$ Istituto Nazionale di Geofisica e Vulcanologia, Sezione Roma 2, Rome, Italy \\ ${ }^{4}$ Instituto Andaluz de Geofisica, Universidad de Granada, Granada, Spain \\ ${ }^{5}$ Università di Genova, Dipartimento di Informatica, Bioingegneria, Robotica e Ingegneria dei Sistemi, Genova, Italy \\ ${ }^{6}$ Nave Ammiraglio Magnaghi, Marina Militare Italiana
}

\author{
Article history \\ Received January 12, 2016; accepted May 6, 2016. \\ Subject classification: \\ Magnetic survey, ROV dives, Mt. Etna offshore, TOMO-ETNA experiment.
}

\begin{abstract}
The TOMO-ETNA experiment was devised for the investigation of the continental and oceanic crust beneath Mt. Etna volcano and northeastern Sicily up to the Aeolian Islands, through an active source study. In this experiment, a large amount of geophysical data was collected both inland and in the Ionian and Tyrrhenian Seas for identifying the major geological and structural features offshore Mt. Etna and NE Sicily. One of the oceanographic cruises organized within the TOMO-ETNA experiment was carried out on the hydrographic vessel "Galatea" by Italian Navy. During the cruise a detailed magnetic survey and a set of ROV (remotely operated vehicle) dives were performed offshore Mt. Etna. The magnetic survey allowed the compilation of a preliminary magnetic map revealing a clear direct relationship between volcanic structures and high frequency magnetic anomalies. Significant positive magnetic anomalies were identified offshore the Timpa area and along the easternmost portion of the Riposto Ridge and correlated to a primitive volcanic edifice and to shallow volcanic bodies, respectively. On the whole, the magnetic anomaly map highlights a clear SW-NE decreasing trend, where high amplitude positive magnetic anomaly pattern of the $S W$ sector passes, northeastwardly, to a main negative one. ROV dives permitted to directly explore the shallowest sectors of the Riposto Ridge and to collect several videos and seafloor samples, allowing us to identify some locally developed volcanic manifestations.
\end{abstract}

\section{Introduction}

The TOMO-ETNA experiment (seismic TOMOgraphy at Mt. ETNA volcano and surrounding areas) was carried out within the Task 5.3 "Mt. Etna structure" of the European project "MED-SUV" (MEDiterranean SUpersite Volcanoes - Long-term monitoring experiment in geologically active regions of Europe prone to natural hazards: the Supersite concept), performed also with the resources of the European project “EUROFLEETS 2" [Ibáñez et al. 2016a, in this volume]. The main objective of the experiment was to gain a detailed geological and structural model of the continental and oceanic crust beneath Mt. Etna volcano and northeastern Sicily up to the Aeolian Islands by performing a high-resolution seismic tomography through active and passive seismic methods accomplished both inland and offshore (either in the Ionian and Tyrrhenian Seas) [Coltelli et al. 2016, in this volume; Ibáñez et al. 2016a, in this volume]. A supplementary goal was the acquisition of geophysical data in the Ionian Sea to identify the main volcano-tectonic structures offshore Mt. Etna through multi-channel reflection seismic, magnetic, gravity and ROV (remotely operated vehicle) surveys. To achieve these objectives, during the second half of 2014, three specific oceanographic cruises were carried out [Coltelli et al. 2016, in this volume]. One of these cruises was performed between June 25 to July 3, 2014, on the catamaran hydrographic vessel (H/V) "Galatea" (Figure 1), provided by the Italian Navy within an agreement with the Istituto Nazionale di Geofisica 


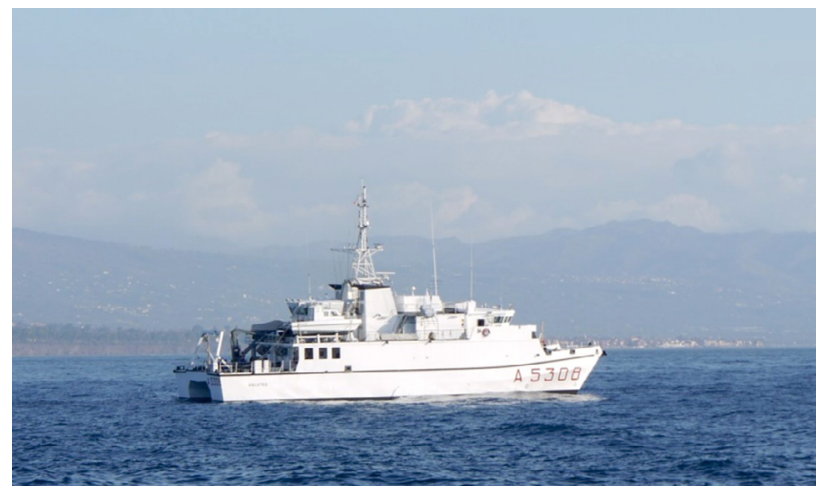

Figure 1. The catamaran $\mathrm{H} / \mathrm{V}$ "Galatea" by Italian Navy.

e Vulcanologia (INGV), for the development of the Italian marine geophysical research (for more details see Coltelli et al. [2016] in this volume).

During this multidisciplinary oceanographic cruise two different acquisition activities were accomplished: a detailed magnetic survey and a set of ROV dives. Several OBSs (ocean bottom seismometers) were also deployed in both the Ionian and Tyrrhenian Seas to register, together with the INGV permanent and temporary seismic networks, the natural seismicity of the area and the airgun shooting generated by the Spanish research vessel "Sarmiento de Gamboa" (UTM-CSIC), for achieving the high-resolution seismic tomography through wide-angle refraction seismic (WAS) method [Coltelli et al. 2016, in this volume; Ibáñez et al. 2016b, in this volume].

The Etna volcano offshore has been object of several works in the last years [Del Negro and Napoli 2002; Pareschi et al. 2006; Patanè et al. 2009; Chiocci et al. 2011; Argnani et al. 2013; among others] with the aim to outline its volcano-tectonic pattern.

Within the TOMO-ETNA experiment, the magnetic survey was realized to obtain a magnetic map offshore the eastern flank of Mt. Etna volcano and to better understand how the volcanism extends eastward. In particular, one of major aims of magnetic survey was to verify and detail the volcanic centres located offshore Timpa area [Corsaro et al. 2002; Del Negro and Napoli 2002; Chiocci et al. 2011], on the Riposto Shoal [Patanè et al. 2009; Argnani et al. 2013] and along the continental slope south of the Riposto Ridge [Patanè et al. 2009] (Figure 2).

Moreover, the new magnetic data improve details and features of the volcanism offshore Etna coast, expanding the knowledge of this area already object of previous magnetic surveys [Del Negro and Napoli 2002;

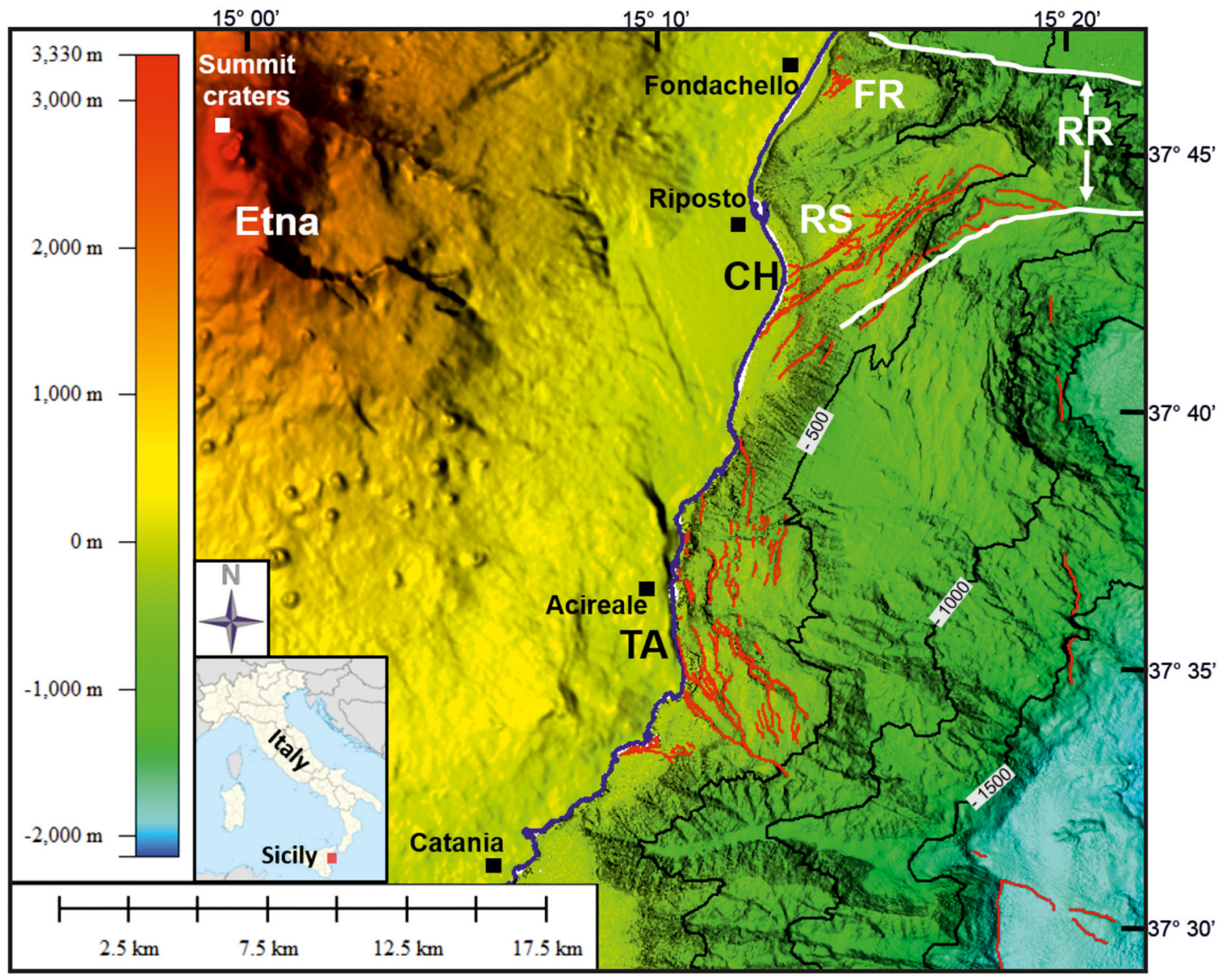

Figure 2. High-resolution bathymetry map (modified from Chiocci et al. [2011]) offshore Mt. Etna with the main interpreted tectonic lineaments (red lines); RR: Riposto Ridge (white lines represent its boundaries), FR: Fondachello Ridge, RS: Riposto Shoal, CH: Chiancone volcanoclastic deposit, TA: Timpa area. The inset displays the study area. 
Nicolosi et al. 2014].

Whereas, ROV dives were planned to directly observe some morpho-structures of high geological interest, previously imaged on the high-resolution bathymetry of the shallow Mt. Etna offshore [Chiocci et al. 2011], with the opportunity to sample seafloor rocks, sediments and gas. In particular, ROV dives were scheduled on top of the Riposto Shoal, where some evidences of volcanics (i.e. lava pillows) have been reported by Patanè et al. [2009] and offshore Fondachello, where several morphological highs were identified through high-resolution bathymetries (Figure 2) and ROV observations by Chiocci et al. [2011].

Several researchers belonging to different sections and units of INGV took part in the cruise on the $\mathrm{H} / \mathrm{V}$ "Galatea": the Geophysics and Marine Technologies unit of Porto Venere for the magnetic and ROV surveys; the Osservatorio Etneo (Etna Observatory) of Catania concerning ROV dives campaign and underwater volcanology; the Section of Palermo for the gas sampling; and the "OBS Lab" unit of Gibilmanna for the OBSs deploying. A ROV pilot by Subonica was also engaged for the ROV activities.

Between June 17 to 23, 2015, an extension of the $\mathrm{H} / \mathrm{V}$ "Galatea" research cruise was performed offshore Mt. Etna volcano using the same vessel, to acquire additional magnetic data and to accomplish a detailed gravity survey, which was not previously realized because of technical issues of the instrumentation [Coltelli et al. 2016, in this volume].

This paper focuses on the description of the acquisition procedures and processing methodologies of magnetic and ROV data collected during the $2014 \mathrm{H} / \mathrm{V}$ "Galatea" oceanographic cruise, showing some preliminary results. It represents one of a group of 11 papers that compose a special volume describing the multidisciplinary topics of the TOMOETNA experiment and some of the first results obtained [Ibáñez et al. 2016b, in this volume].

\section{Planning and acquisition proce- dures}

The planning of all data acquisition procedures to be carried out on board the H/V "Galatea” repre- sented a fundamental step in the success of the cruise. It was made taking into account the available ship-time in function of the eventual occurrence of typical complications of the marine scientific activities, such as bad weather and sea conditions and technical problems. A contingency plan was also arranged: in the event that one or more activities should be carried out slower/faster than scheduled, some others to delete/add were also programmed. For logistic reasons it was planned to perform the magnetic survey mostly during the nighttime and ROV dives exclusively during the morning, even to facilitate the equipment deployment and recovery operations.

\subsection{Magnetic survey}

A layout of magnetic survey was scheduled on the basis of seabed morphology (high-resolution multibeam bathymetric data; Chiocci et al. [2011]; Figure 2) and the regional magnetic anomaly field coming from previous works [Chiappini et al. 2000; Del Negro and Napoli 2002; Caratori Tontini et al. 2004]. The 2014

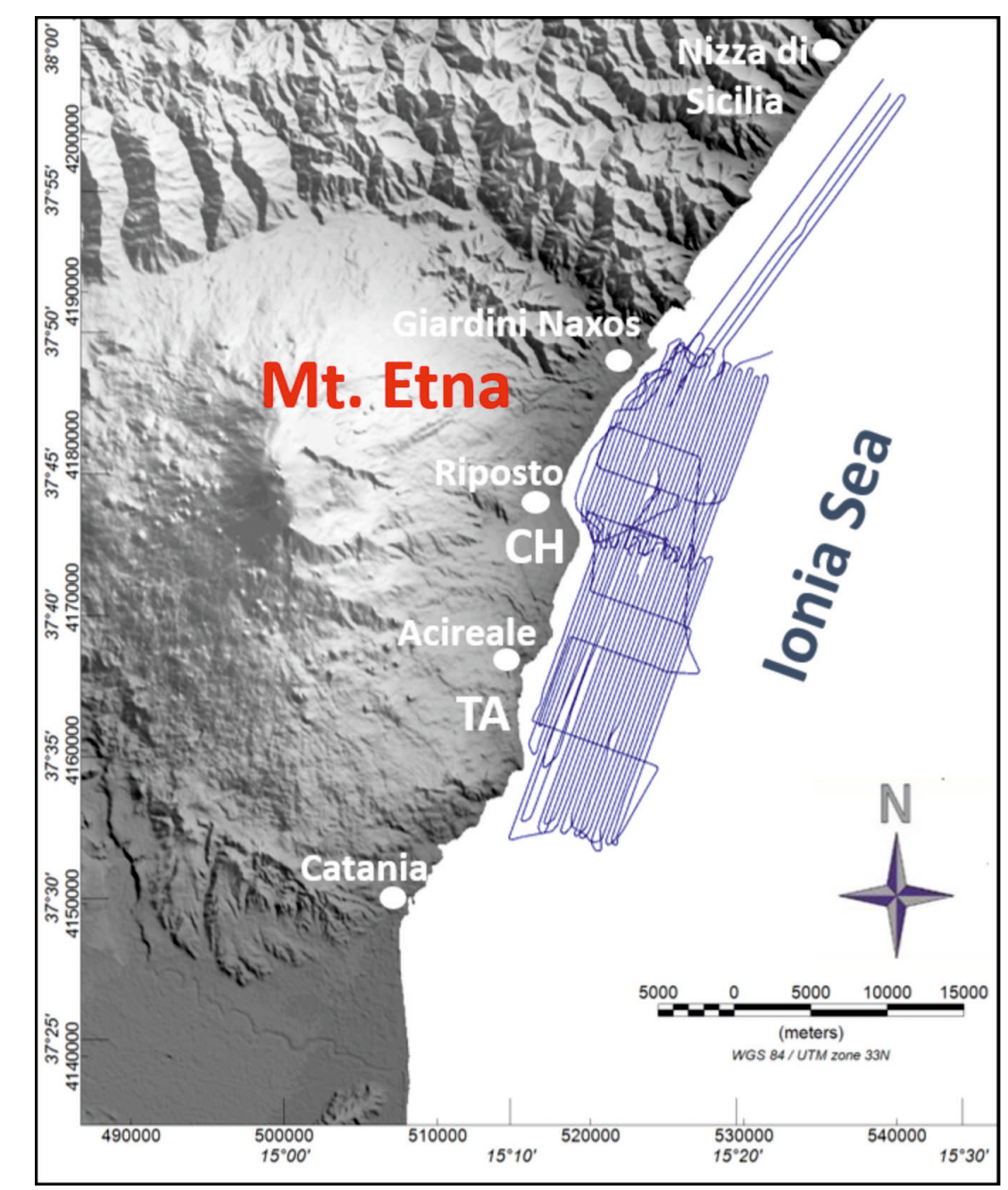

Figure 3. Track lines of the magnetic survey offshore Mt. Etna volcano. $\mathrm{CH}$ (Chiancone volcanoclastic deposit), TA: Timpa area. 
magnetic survey was planned using a line-path oriented along NE-SW direction (Figure 3) in order to intersect the major volcano-tectonic features occurring offshore Mt. Etna (Figure 2). Several other tie-lines were also planned along an orthogonal NW-SE orientation to intersect the main ones, in way to achieve a set of crossover points useful for the subsequent levelling procedure.

The magnetic data were acquired in some geologically relevant areas such as: the Riposto Ridge (a prominent $\mathrm{E}-\mathrm{W}$ trending structure located offshore the homonymous town and considered the underwater extension of the Sicilian Apennine Chain; Chiocci et al. [2011]); the submarine extension of the Chiancone (a huge volcanoclastic fan-deposit located along the eastern Etna coast); offshore Timpa (a NNW-SSE fault-controlled sea-cliff located on the western margin of an old submerged volcanic edifice; Corsaro et al. [2002]; Chiocci et al. [2011]); offshore the coast between Giardini Naxos and Nizza di Sicilia (where the underwater extension of the Tindari-Letojanni fault was supposed to be located by Lanzafame and Bousquet [1997]).

Ship-borne magnetic data were collected using a Geometrics G880 caesium-pumped marine magnetometer (Figure 4), towed about $180 \mathrm{~m}$ astern of the $\mathrm{H} / \mathrm{V}$ "Galatea" (for technical specifications see Coltelli et al. [2016] in this volume).

Earth's magnetic fields were sampled at $1 \mathrm{~Hz}$ by using the specific Geometric's MagLog software suite, which also provided a real time GPS lay-back-correction of tow-fish position. Moreover, precise positioning was ensured by differential correction by using a Fugro Marinestar VBS.

The tow-fish was deployed into the sea through a small crane. Due to the shallow water of the surveyed area and the long layback of the tow-fish, this last was equipped with a small floating tool (Figure 4), in way to confer a constant attitude of the magnetometer, even in case of vessel speed reduction for both the safety of the equipment and the accuracy of the results.

During the initial stage of the survey, a set of tests to identify the effect of eventual magnetic noise induced by the ferromagnetic portions of the vessel was also provided.

We collected magnetic data at different time incrementing step by step (every 50 meters) the distance between the tow-fish and the stern; the right position of the magnetometer was fixed once the noise induced by the vessel was roughly minimized. Nevertheless, effects of induced field from the ferromagnetic parts of the vessel (mainly built in fiberglass) slightly affected the collected data addressing a heading correction (see Section 3.1). During the survey the magnetic data were treated with a preliminary quality control in way to remove eventual instrumental errors (i.e. spikes).

The magnetic survey was conducted following a navigation speed of about 6 knots, which represents a good compromise between the time-ship dedicated to the survey and the accuracy of collected data, since a greater speed may introduce geometrical instability of the tow-fish (i.e. tilting and rapid heading variation), triggering high frequency noise and intervening spikes. During the first part of the survey, the magnetic data were slightly affected by high frequency noise. This effect was probably due to the not constant speed of the vessel combined to the sea state, which triggered a "yo-yo like effect" (up and down oscillations) of the tow-fish with an overlaying of low-amplitude (about $\pm 10 \mathrm{nT}$ ) noise-related signal. This erroneous pattern was filtered out during the post-acquiring stage applying, just on the selected lines, a simple low-pass filtering at 20 seconds.

The 2014 magnetic survey was carried out following a set of 64 roughly NE-SW (heading $\mathrm{N} 30^{\circ}$ ) parallel
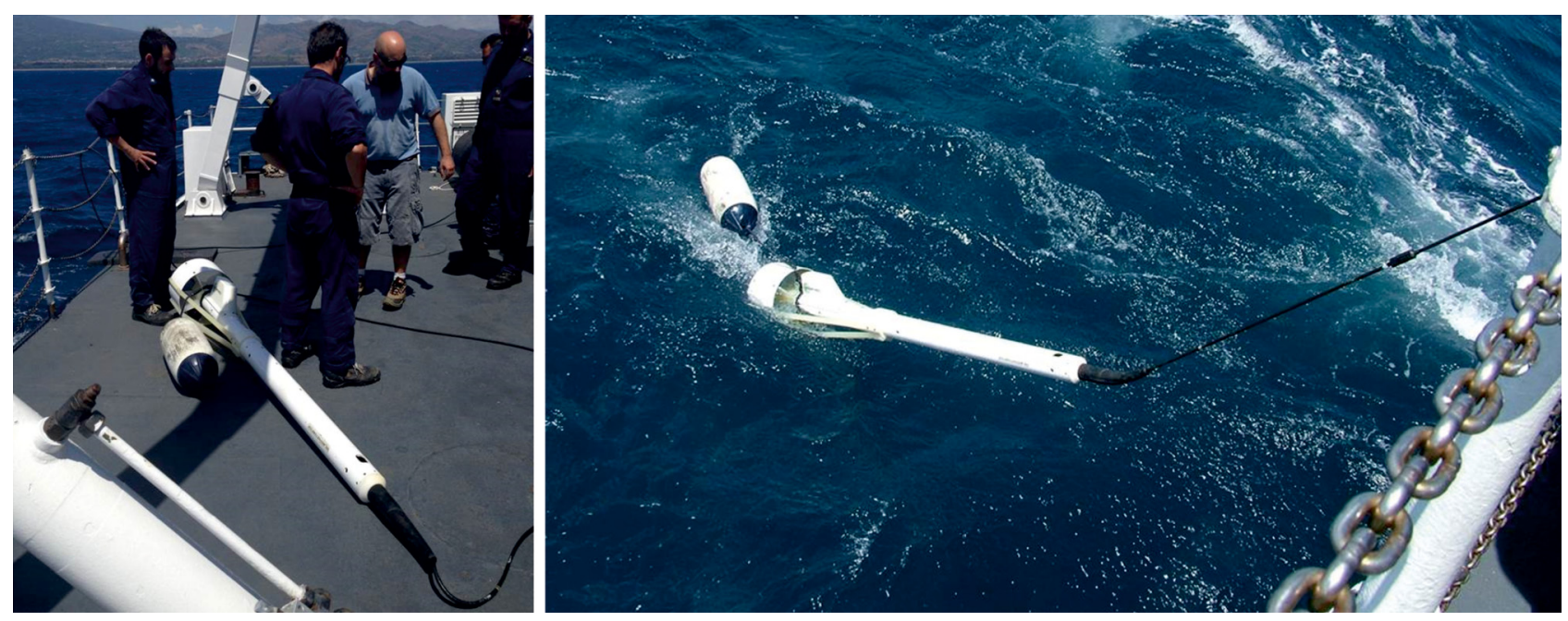

Figure 4. The Geometrics G880 caesium-pumped marine magnetometer on board the H/V "Galatea" (left) and during its deployment (right) together with a small floating tool to guaranty the correct and safety buoyancy. 
track lines, spaced some $300 \mathrm{~m}$ apart and 6 orthogonal (heading $\mathrm{N} 290^{\circ}$ ) control tie lines (Figure 3). The planned magnetic survey was successfully achieved in about 48 hours of data acquisition. During the survey we needed to change only a few times the track lines direction because of the occurrence, along the planned routes, of some fishing nets. The resulting dataset counts about more than 1,651,000 data records collected along about 1340 linear $\mathrm{km}$.

\subsection{ROV dives}

ROV dives were planned to explore some relevant morphological targets located in shallow water offshore Mt. Etna, previously identified, on the basis of the highresolution multibeam bathymetric data, by Chiocci et al. [2011]; they were scheduled taking into account several parameters such as the depth of the seafloor in function of the ROV operating depth, the presence of strong marine currents, the distance to the coast (as regard the safety limitations), etc. The ROV dives campaign was carried out using a ROV Sirio by Ageotec (operating depth $300 \mathrm{~m}$ ), provided by Geophysics and Marine Technologies unit of Porto Venere of INGV, and belonging to the ROV Observer Class for visual inspections (Figure 5); for more detailed technical specifications of the ROV see Coltelli et al. [2016, in this volume].

The ROV was preliminary arranged with a manipulator (with two different possible motions: up-down and left-right) to collect seafloor samples. If necessary, the manipulator could be replaced by a small grab sampler to collect some sediment from the sea bottom. Moreover, a gas sampler was specifically set on the manipulator for this cruise to be used in case of identification of gas bubbles released from fumarole fields [Coltelli et al. 2016, in this volume]; unfortunately no gas emission was detected during the dives and the device was not used.

During the dives, to guaranty a safety distance of the ROV umbilical to the ship's engines, a buoy was put at some $20 \mathrm{~m}$ from the vessel. To favourite the ROV navigation, the ship movement was minimized by using its thrust engines. Because of very strong marine currents the ROV navigation was sometimes very laborious, especially in late afternoon when they were stronger. Another serious difficulty for ROV navigation was represented by the large amount of abandoned fishing nets occurring on the rocky top of the Riposto Shoal.

The real time positioning of the ship was obtained through the main navigation system (Trimble DGPS) through Seapath interface linked to QPS QINSy software. The ROV was not equipped with an acoustic beacon for a real time linkage with the vessel; therefore its positioning on the seafloor was achieved deploying the ROV very close to the point of inspection and com-

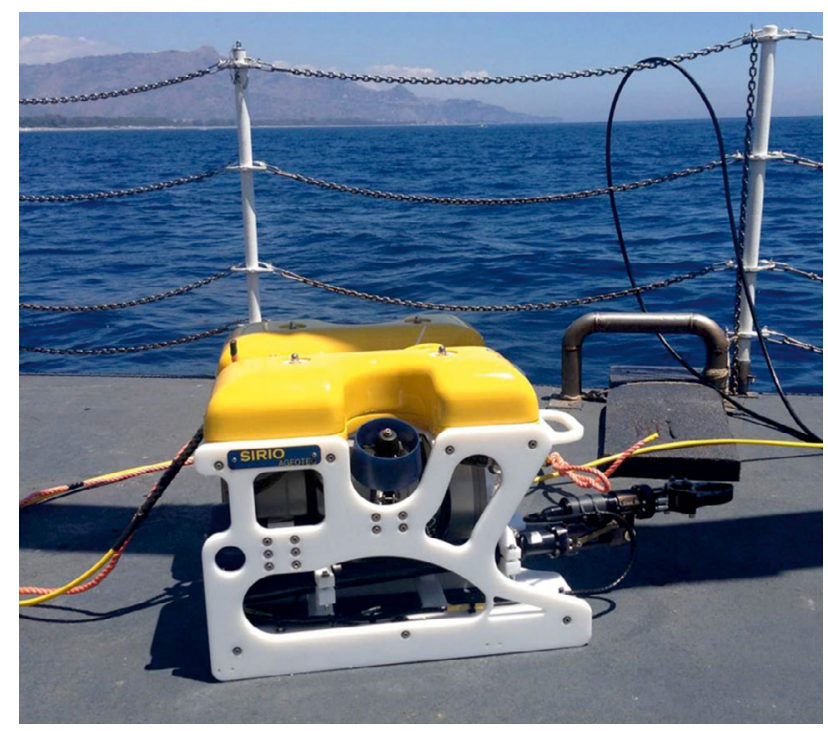

Figure 5. The Sirio ROV by Ageotec used during the cruise.

paring in real time the morphological features, occurring on the high-resolution multibeam bathymetry [Chiocci et al. 2011] plotted on the ship's navigation system, with those framed by the camera. The navigation was also helped by checking continuously the layback distance and using read-out compass, depth and heading values displayed on the video console.

During the first ROV dive, we verified an incongruity between the values of the ROV depth, shown on the video console, with those indicated on the high-resolution multibeam bathymetry [Chiocci et al. 2011]. To resolve this technical issue, due to an offset of the ROV pressure sensor, a scuba diving depth gauge was applied to the ROV chassis in a suitable position to be easily framed by the camera during the dives (Figure 6). In this way, we verified that the depth values were affected by a constant overestimation of about $9 \%$. The solution of this technical issue was fundamental to record

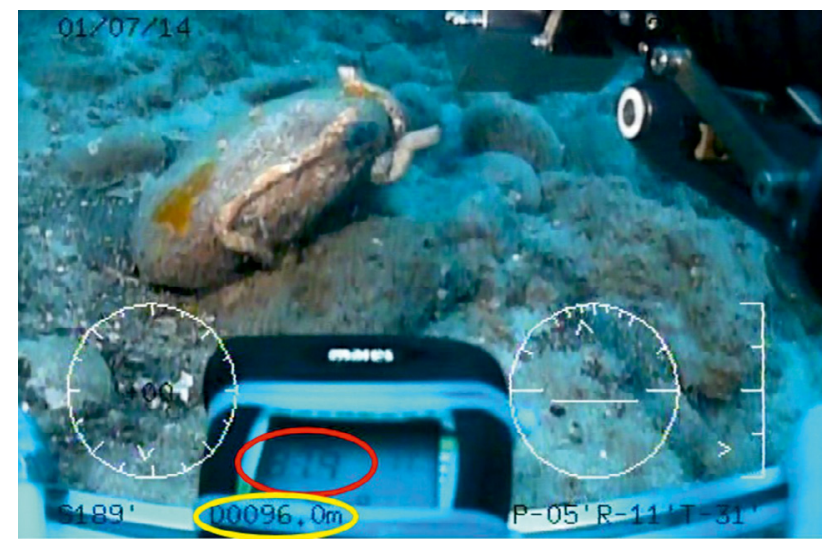

Figure 6. Picture extrapolated from a ROV video highlighting the technical issue of the pressure sensor during the ROV survey inferred by the difference between the depth values displayed on the video console (yellow oval) and on the depth gauge appositely applied on the ROV chassis (red oval). 


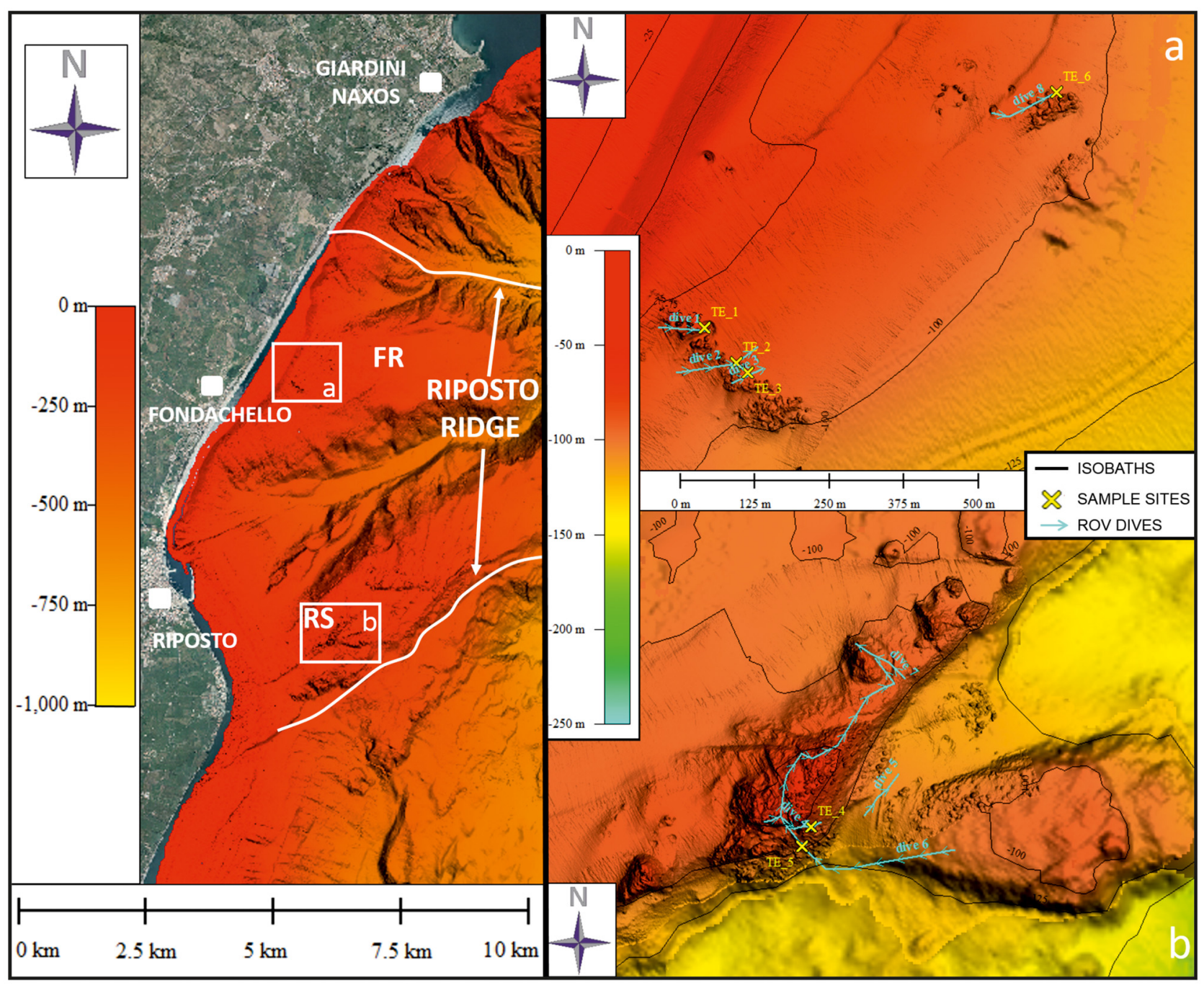

Figure 7. ROV dives (with indication of the sample sites) carried out on the shallowest portion of the Riposto Ridge: FR (Fondachello Ridge), RS (Riposto Shoal).

the true depth during the next dives.

On the whole, 8 ROV dives were carried out, covering about 1.5 linear $\mathrm{km}$ along 11 transects (Figure 7) and recording about 10 hours of high resolution seafloor video. The dives focused on the Riposto Ridge, a marked E-W trending feature, which includes, in its westernmost portion, the Fondachello Ridge and the Riposto Shoal. Dives 1, 2, 3 and 9 crossed the shallowest portions of the Fondachello Ridge (offshore Fondachello village), where several seabed highs were previously detected on high-resolution bathymetries [Chiocci et al. 2011]. Dives from 4 to 7 explored the Riposto Shoal, a NE-SW trending complex structure, deeply affected by steep scarps, located about $2.3 \mathrm{~km}$ far from the shoreline with the top situated at water depth of $66 \mathrm{~m}$, where underwater volcanic products have been reported by Patanè et al. [2009].

A total of six seafloor samples were also collected on both the two spots (Figure 7); they were catalogued and roughly examined on the ship during the cruise (Table 1).

\section{Processing methodologies}

Hereinafter we document the main processing procedures applied to magnetic and ROV data.

\subsection{Magnetic data}

Firstly, systematic navigation errors have been successfully removed assuming a constant layback distance.

Total-field magnetic data were processed removing spikes and outliers. Additional heading correction was required to minimize intervening residual effects due to dipolar magnetic field generated by the vessel. This correction was applied by estimating a corrective matrix, computed applying statistical evolution of the total magnetic field (TMF) acquired at different heading directions. The distribution of the survey lines provided a statistic about average TMF values for 8 main heading directions $(0,30,120,150,180,210,270,300$ and 330 degrees) (see Table 2).

Although we were not able to install a coherent magnetic base station close to the surveyed area (as indicated by Faggioni and Caratori Tontini [2002]), we cor- 


\begin{tabular}{|c|c|c|c|c|c|c|c|}
\hline $\begin{array}{c}\text { Date } \\
\text { (dd/mm/yyyy) }\end{array}$ & $\begin{array}{l}\text { Dive } \\
\text { No. }\end{array}$ & Location & Lat & Long & $\begin{array}{l}\text { Depth } \\
(\mathrm{m})\end{array}$ & Sample & $\begin{array}{c}\text { Sample } \\
\text { description }\end{array}$ \\
\hline $28 / 06 / 2014$ & 1 & $\begin{array}{l}\text { Fondachello } \\
\text { Ridge }\end{array}$ & $37^{\circ} 45.59^{\prime} \mathrm{N}$ & $15^{\circ} 13.59^{\prime} \mathrm{E}$ & $75-85$ & TE_1 & sub-rounded pebble \\
\hline $28 / 06 / 2014$ & 2 & $\begin{array}{l}\text { Fondachello } \\
\text { Ridge }\end{array}$ & $37^{\circ} 45.57^{\prime} \mathrm{N}$ & $15^{\circ} 14.05^{\prime} \mathrm{E}$ & $80-85$ & TE_2 & $\begin{array}{l}\text { sub-rounded lava pebble } \\
(14 \times 8 \mathrm{~cm}) \text { located at the base } \\
\text { of a morphological high }\end{array}$ \\
\hline $28 / 06 / 2014$ & 3 & $\begin{array}{l}\text { Fondachello } \\
\text { Ridge }\end{array}$ & $37^{\circ} 45.56^{\prime} \mathrm{N}$ & $15^{\circ} 14.05^{\prime} \mathrm{E}$ & $80-90$ & TE_3 & $\begin{array}{l}\text { very rounded metamorphic } \\
\quad \text { pebble }(\mathrm{d} \approx 10 \mathrm{~cm})\end{array}$ \\
\hline $29 / 06 / 2014$ & 4 & $\begin{array}{l}\text { Riposto } \\
\text { Shoal }\end{array}$ & $37^{\circ} 43.16^{\prime} \mathrm{N}$ & $15^{\circ} 14.31^{\prime} \mathrm{E}$ & $70-85$ & TE_4 & $\begin{array}{c}\text { reddish lava block } \\
\text { abundantly covered } \\
\text { by encrusting organisms }\end{array}$ \\
\hline $29 / 06 / 2014$ & 5 & $\begin{array}{l}\text { Riposto } \\
\text { Shoal }\end{array}$ & $37^{\circ} 43.16^{\prime} \mathrm{N}$ & $15^{\circ} 14.38^{\prime} \mathrm{E}$ & $105-115$ & l & / \\
\hline $30 / 06 / 2014$ & 6 & $\begin{array}{l}\text { Riposto } \\
\text { Shoal }\end{array}$ & $37^{\circ} 43.14^{\prime} \mathrm{N}$ & $15^{\circ} 14.44^{\prime} \mathrm{E}$ & $70-130$ & TE_5 & $\begin{array}{l}\text { grey lava massive block } \\
\text { partially covered } \\
\text { by encrusting organisms }\end{array}$ \\
\hline $30 / 06 / 2014$ & 7 & $\begin{array}{l}\text { Riposto } \\
\text { Shoal }\end{array}$ & $37^{\circ} 43.24^{\prime} \mathrm{N}$ & $15^{\circ} 14.41^{\prime} \mathrm{E}$ & $85-105$ & l & l \\
\hline $01 / 07 / 2014$ & 8 & $\begin{array}{l}\text { Fondachello } \\
\text { Ridge }\end{array}$ & $37^{\circ} 46.13^{\prime} \mathrm{N}$ & $15^{\circ} 14.27^{\prime} \mathrm{E}$ & $85-110$ & TE_6 & $\begin{array}{l}\text { light grey sandy } \\
\text { organogenic sediment }\end{array}$ \\
\hline
\end{tabular}

Clockwise from top: Table 1. Summary and main description of the samples collected by ROV during the cruise. Figure 8. Map of difference between levelled magnetic anomaly and raw data. Grid cell size is $200 \mathrm{~m}$. In light grey, the survey track lines are overlaid. In the inset, the detailed histogram statistic distribution of crossover errors is reported. $\mathrm{CH}$ (Chiancone volcanoclastic deposit), TA (Timpa area). Table 2. Heading correction table obtained computing the mean magnetic values for each different heading direction and subtracting these from the average magnetic anomaly field of the whole area $(-70.49 \mathrm{nT})$.

\begin{tabular}{cc}
\hline $\begin{array}{c}\text { Heading direction } \\
(\text { degree })\end{array}$ & $\begin{array}{c}\text { Correction } \\
(\mathbf{n T})\end{array}$ \\
\hline 0 & -8.89 \\
\hline 30 & -12.59 \\
\hline 120 & -69.97 \\
\hline 150 & -34.52 \\
\hline 180 & 79.16 \\
\hline 210 & 2.32 \\
\hline 300 & -24.58 \\
\hline 30 & 67.33 \\
\hline
\end{tabular}

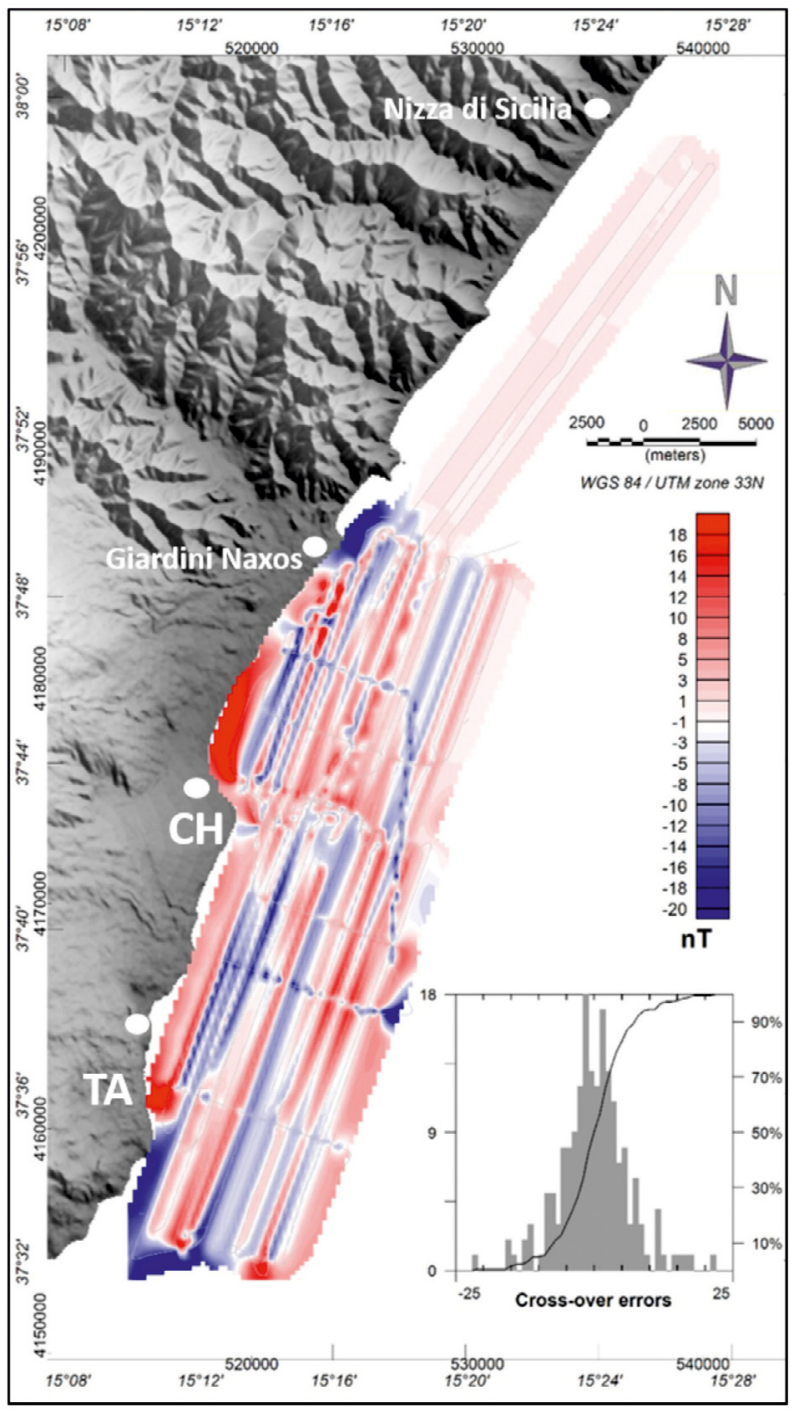


rected the diurnal variation of Earth's magnetic field considering the time-series carried out from INGV Duronia geomagnetic observatory (node of InterMagnet). Total intensity magnetic anomaly field was calculated by subtracting the International Geomagnetic Reference Field (IGRF) from the total field data [e.g. Finlay et al. 2010].

Thus, the computed magnetic anomaly dataset was processed to minimize not-systematic errors (i.e. not constant speed of the vessel, vertical movement of the tow-fish due to the wave motion) applying a levelling procedure. Uniform distribution of tie lines over the entire survey area was useful to define a dense crossover error surface. In total crossover errors are in $\pm 21 \mathrm{nT}$ range. A complete levelling procedure was achieved by means of a statistical approach counting differences directly from double measurement points between two crossed lines and also gradient values computed between adjacent lines (Figure 8).

\subsection{ROV data}

The ROV navigation was plotted on the bathymetry map (using the Global Mapper software) and linked with frames, extracted from the high-resolution video recordings, showing some spots of particular relevance. The videos were accurately examined and their useless parts were cut out, for a detailed multi-viewpoint morphological analysis of the explored seafloor structures and for the validation of the geological features imaged on the high-resolution bathymetric map [Chiocci et al. 2011].

\section{Preliminary results}

Hereinafter we present some results of the $\mathrm{H} / \mathrm{V}$ "Galatea" 2014 oceanographic cruise regarding both magnetic and ROV surveys; these data must be considered as preliminary results, since they need to be further correlated each other as well as with the other available data coming from the TOMO-ETNA experiment.

\subsection{Magnetic map of Mt. Etna offshore}

The magnetic survey carried out in 2014 allowed to realize a detailed magnetic map (Figure 9) offshore Mt. Etna, highlighting the occurrence of some relevant magnetic anomalies.

Moreover, we performed a reduced to the pole (RTP) magnetic anomaly map to better define the positioning of magnetic sources. RTP elaboration mainly addresses a phase shifting in FFT (fast Fourier transform) domain, which transforms the shape of magnetic anomaly from dipolar (as observed at medium latitude) to monopolar, as if it has been acquired at the magnetic pole. This approach permits to better localize the positioning of the magnetic sources which would be located at the maximum of the RTP anomaly. Results of this pro- cedure are shown in Figure 10. RTP magnetic anomaly map highlights a clear SW-NE decreasing trend, where the high amplitude positive magnetic anomaly pattern of the SW sector passes to a main negative one in the northeastern area. Negative values are not correlated to magnetize signature of the rock acquired during reverse magnetic chron, but rather they are related to a strong regional field due to the presence of a large dipole of Etna volcano which still remains also after the RTP procedure. Anyway, RTP map clearly reveals the direct relationship between shallow volcanic structures and high frequency magnetic anomalies. We attempted to quantitatively interpret the depth of several magnetic sources approaching the well-consolidated 3D Euler deconvolution methods. The depth distribution of the centroid of the magnetic sources was computed by Euler's deconvolution [Reid et al. 1990; Fitzgerald et al. 2004], applying a least squares inversion of the Euler's homogeneity equation to the magnetic anomaly data [Thompson 1982] using a structural index (SI) equal to 1 (tabular structures and/or dike intrusions). The structural index is correlated to the geometry of the sources present in the region of interest. In our case of study, we performed several tests by varying SI values (from 0 to 3 ). The optimal SI value was determined to be the 1 , since it represents the most reliable nature of the sources providing also the highest clustering of the solutions. Deconvolution algorithm was interactively applied using fixed-size dynamic windows that covered the entire magnetic anomaly grid. The size of the dynamic windows is a discriminating parameter that can lead to ambiguous results. The window was dimensioned to be large enough (window size of $600 \mathrm{~m}$ ) to include the anomalies of interest and, at the same time, to avoid the effects of multiple anomalies.

The depth estimation was applied using an iterative method that obtained a set of solutions for each step. The resulting dataset was constrained by filtering out the solutions having a depth uncertainty greater than $10 \%$. The overall depth solutions were checked and referenced to the related depth below sea floor (b.s.f.). The overall datasets counts 768 solutions ranging from a minimum of $122 \mathrm{~m}$ to a maximum of $1267 \mathrm{~m}$ b.s.f.

The area offshore Timpa shows a high amplitude $(>700 \mathrm{nT})$ magnetic anomaly associated with the main structural features (NW-SE trending faults and probable volcanic dykes), suggesting a clear interplay between the tectonic setting and the volcanic manifestations (Figures 9 and 10). Here the Euler's solutions are displayed along the main morphologic structures suggesting the occurrence of clusters of dykes or tabular bodies located between 500 and $800 \mathrm{~m}$ b.s.f. (Figure 10). This evidence is compatible with the remnant portions of the ancient shield volcano located offshore Timpa area 


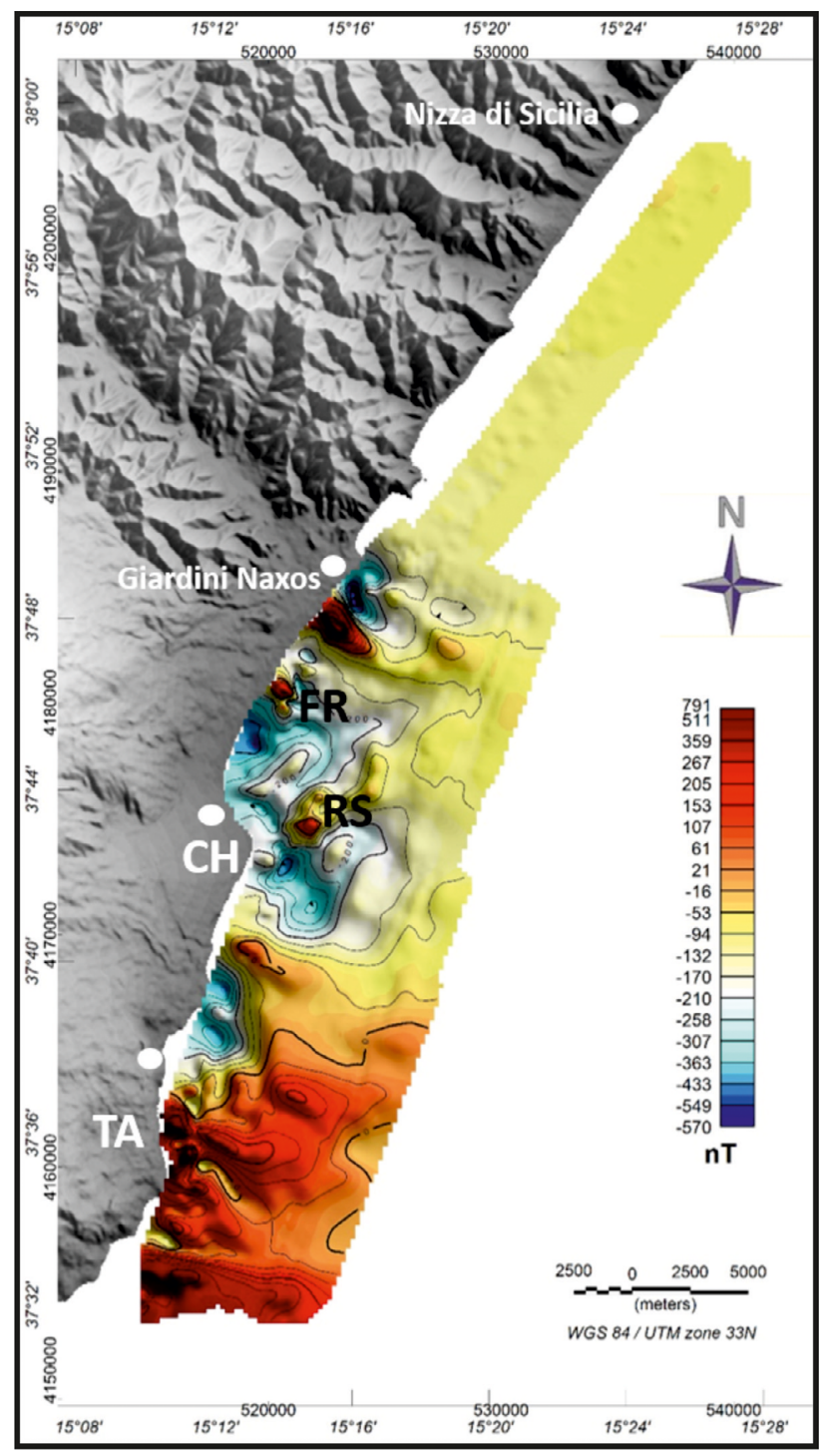

Figure 9. Total intensity magnetic anomaly field offshore Mt. Etna. Grid cell size is $200 \mathrm{~m}$; contours intervals are every $50 \mathrm{nT}$. CH (Chiancone volcanoclastic deposit), TA (Timpa area), TSC (Timpa sea-cliff), RS (Riposto Shoal), FR (Fondachello Ridge).

[Corsaro et al. 2002; Chiocci et al. 2011], which was disrupted and modified by erosive and tectonic processes during the time, since its formation more than $220 \mathrm{ka}$ ago [Branca et al. 2011].

Interesting magnetic features are also observed on the easternmost portion of the Riposto Ridge, since two small high-frequency positive anomalies $(100 \mathrm{nT})$ are placed on two structural highs, the Riposto Shoal and the Fondachello Ridge (Figures 9 and 10). In this sector the Euler's solutions are clustered at very shallow positions (100-200 $\mathrm{m}$ b.s.f.) suggesting the lack of deep roots for these two anomalies (Figure 10). They are mostly related to lavas flown over or intruded within the sedimentary sequences of the basement.

The high-frequency positive anomaly recorded offshore Giardini Naxos is related to the underwater ex-

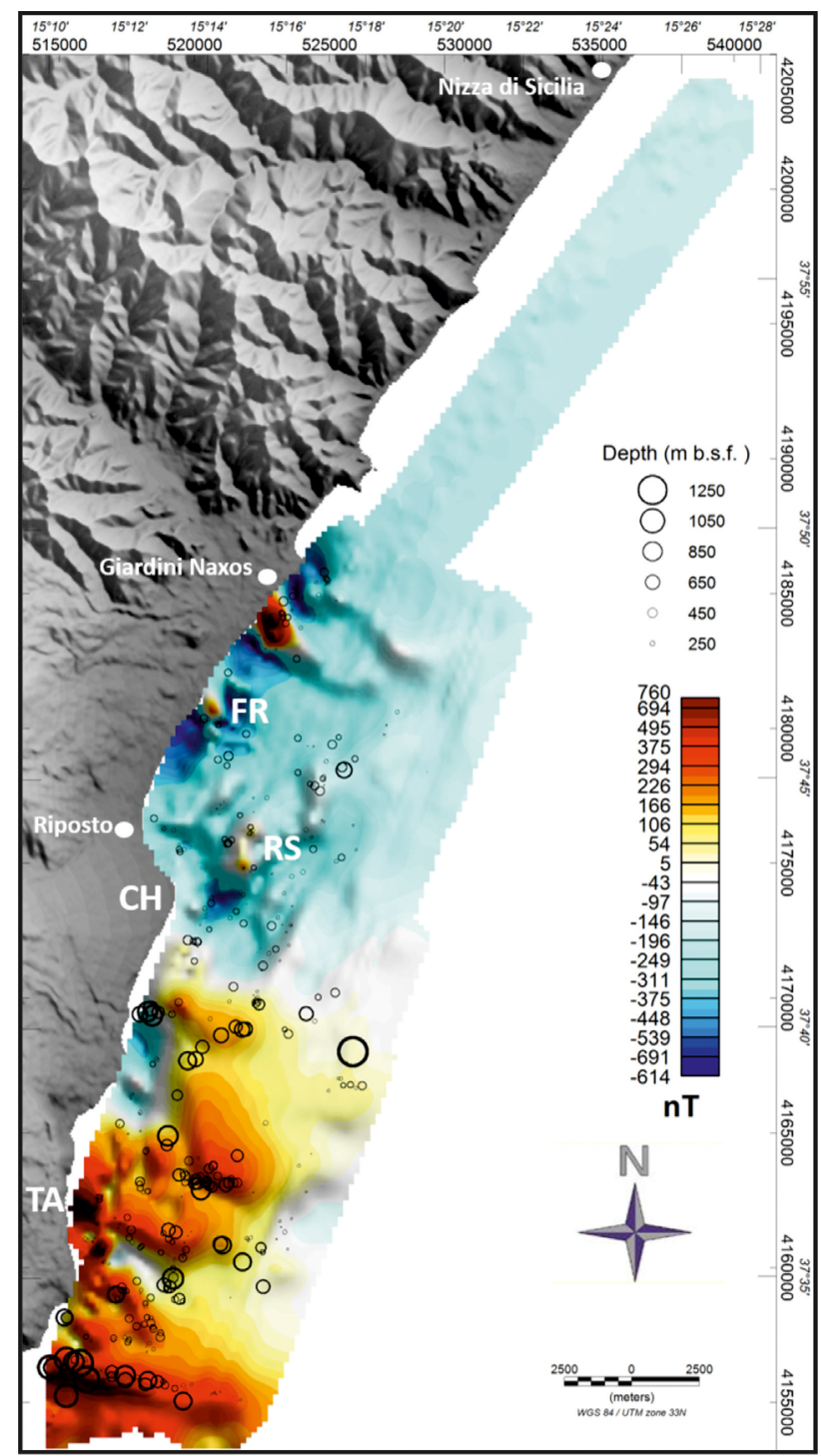

Figure 10. Reduced to the pole magnetic anomaly map (inclination $53.3^{\circ}$; declination $2.9^{\circ}$ ) offshore Mt. Etna. Grid cell size is $200 \mathrm{~m}$. Unfilled black circles indicate the geographical positions of Euler's deconvolution magnetic sources. $\mathrm{CH}$ (Chiancone volcanoclastic deposit), TA (Timpa area), RS (Riposto Shoal), FR (Fondachello Ridge).

tension of the Alcantara lava flow (as previously inferred by Del Negro and Napoli [2002]), which produces high magnetic signals; while the magnetic data acquired offshore the coast between Giardini Naxos and Nizza di Sicilia do not show any evidence of the inferred SE extension of the Tindari-Letojanni fault system [Lanzafame and Bousquet 1997].

Finally, no evidences on magnetic data (Figures 9 and 10) of the presence of an ancient volcanic edifice were found along the continental slope, south of the Riposto Ridge, as supposed by Patanè et al. [2009].

The first results of the magnetic survey show, in correspondence of the southern sector of the surveyed area, a large and intense magnetic positive anomaly related to deep (about $1200 \mathrm{~m}$ b.s.f.) sources (Figure 10). Unfortunately the related magnetic anomaly pattern 
was not properly described due to a southward limited survey covering. This leaded us to plan an extension of the survey (accomplished in 2015 with the same H/V "Galatea"), during which additional magnetic data, together with new gravity profiles, were collected [Coltelli et al. 2016, in this volume].

\subsection{ROV dives observations}

Video recordings and observer notes collected during ROV dives were examined to characterize the main morpho-structural features, e.g., lava bodies, fault scarps, fractures and joints. Moreover, the rock samples collected during the dives were macroscopically examined to distinguish their lithology and mineralogy (Table 1).

On the Riposto Shoal, ROV dives provided evidences of volcanic blocks and lava flows, only partially incrusted, located in water depth ranging from 65 to 130 $\mathrm{m}$. The lithological analysis of the samples recovered by ROV (Figure 11 and Table 1) confirmed the volcanic nature of the outcrops on the shoal. The morphology of the lava flows (similar to those erupted inland by Etna volcano) and the lack of pillows lava and hyaloclastic breccia deposits (typical rocks of underwater volcanic eruptions) suggest a subaerial emplacement of these volcanic products, probably erupted during a lowstand of sea level. This inference is only partially in agreement with the interpretation of Patanè et al. [2009], who firstly identified the volcanic manifestations on the shoal, but hypothesizing their underwater emplacement. On top of the shoal, between 70 to $100 \mathrm{~m}$ water depth, several moundslike structures, tens of meter large with a height up to 15 $\mathrm{m}$, were also observed (Figure 11). All around their base piles of decimetre-size pebbles were also seen. The deposit was sampled by ROV and lithologically examined, confirming the volcanic nature of the pebbles (Table 1).

Off Fondachello beach, in water depths between 70 to $150 \mathrm{~m}$, several other morphological highs have been identified by Chiocci et al. [2011]. ROV dives, carried out on the Fondachello Ridge, shown a hard massive lithology of some of them, with conchoidal fractures (Figure 12) and columnar joints, typical of volcanic outcrops. Others were up to $4 \mathrm{~m}$ high mounds-like structures (Figure 12), showing a sub-rounded shape; at their base a well-sorted deposit of decimetre-size lava and metamorphic pebbles was observed and sampled by ROV (Table 1). This deposit could represent a paleo-beach formed during a lowstand of sea level, as suggested by the actual polygenic coastal deposits, made by reworked pebbles coming from both the sedimentary/metamorphic Sicilian Apennine Chain and northeastern flank of Etna vol-
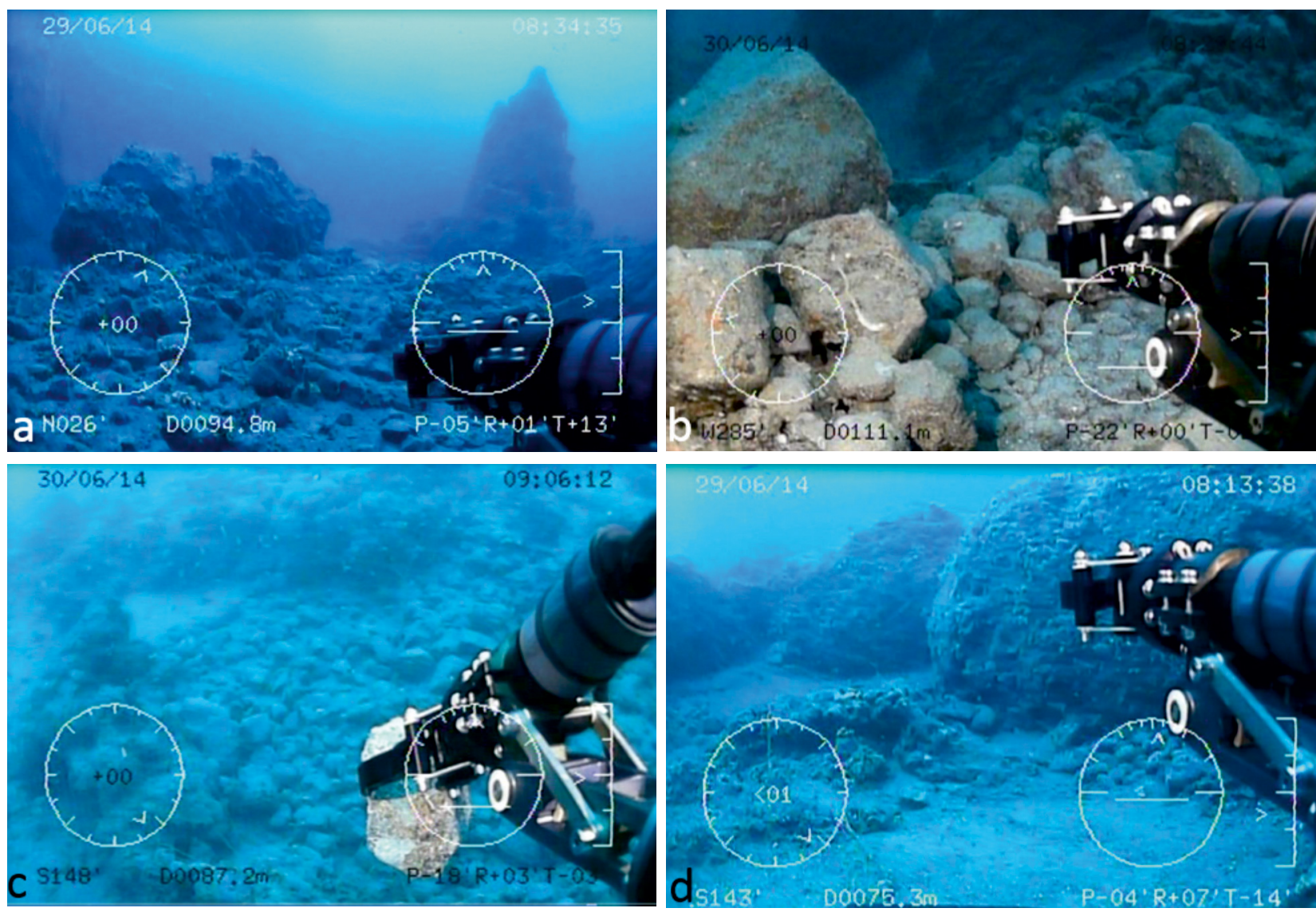

Figure 11. ROV images on top of the Riposto Shoal showing: (a) large blocks at about $-85 \mathrm{~m}$; (b) and (c) a seafloor sampling along a lava rock talus; $\mathrm{d}$ ) one of the mounds-like structures localized in the area. 

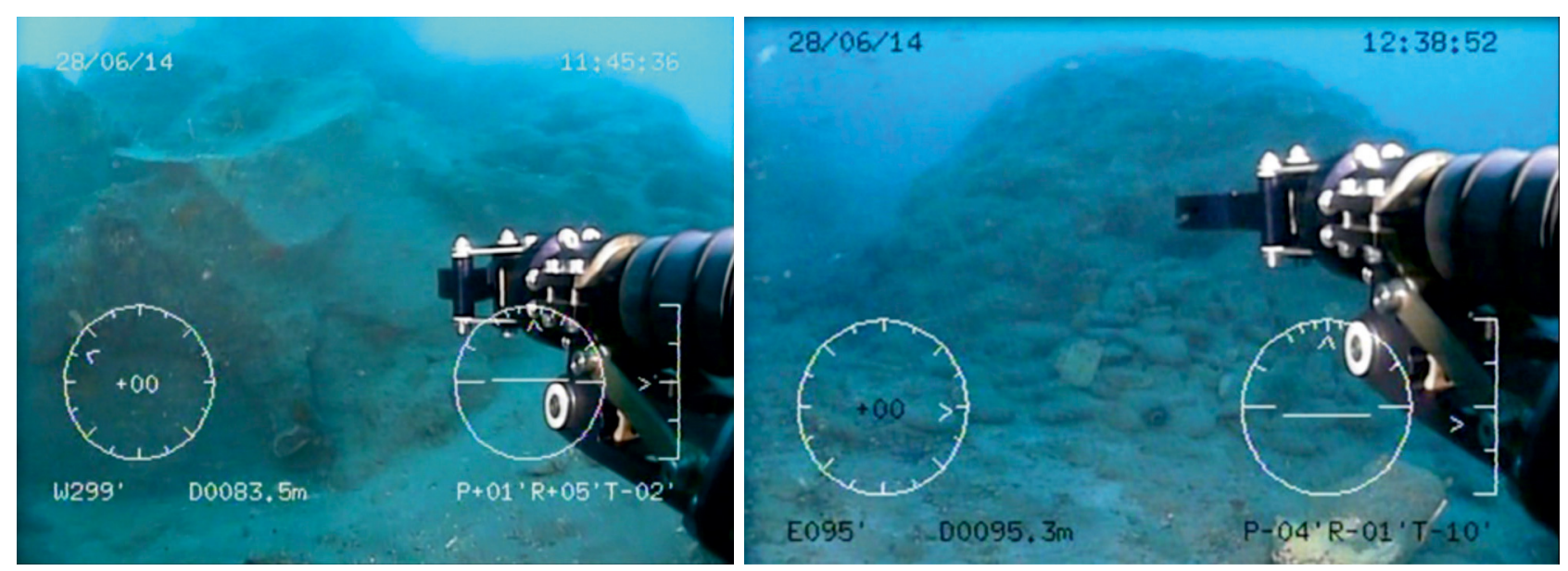

Figure 12. ROV images on Fondachello Ridge displaying, on the left, the outcrop at some $76 \mathrm{~m}$ b.s.l. of a massive lava block characterized by conchoidal fractures and, on the right, a mounds-like structure showing a sub-rounded shape with, at its base, a pebble deposit.

cano. Whereas the deposits observed around the mound structures on the Riposto Shoal are probably due to the sea erosion of in-situ volcanic structures, probably intrusions, since the shoal is too far from the coast, from which it is separated through a saddle, ruling out a terrigenous origin of lava flows. The pebbles forming the deposits in both places were well-exposed (Figures 6, 11 and 12) due to strong littoral currents sweeping out the sediment.

Finally, no evidences of gas emissions were found on whole the investigated area.

\section{Conclusive remarks}

The results, presented in this paper, must be considered as preliminary data, since they need to be better correlated with other geophysical data acquired during the TOMO-ETNA experiment and previous surveys, as well as compared with INGV earthquake and volcano monitoring data. All the seafloor samples, for instance, need detailed petrographic and chemical analysis, in way to be associated with the products erupted inland and then correlated with a specific stage of the volcanic evolution of Mt. Etna [Branca et al. 2011]. Moreover, samples as well as ROV observations have to be compared to other seafloor rocks coming from dredges and ROV images collected in the area during previous oceanographic cruises.

The results of the magnetic survey showed, in correspondence of the southern sector of the surveyed area, a large and intense magnetic positive anomaly related to deep sources (Figure 10); conversely, in the northern offshore area, high frequency RTP magnetic anomalies associated to shallow volcanic manifestations are placed over a low magnetized sedimentary sequence of the basement.

A first correlation between magnetic and ROV data allows us to identify on the easternmost portion of the Riposto Ridge some locally developed volcanic structures. ROV data (observations and seafloor samples) val- idate the results of the magnetic survey and vice versa, highlighting the presence of volcanics on both the Riposto Shoal and Fondachello Ridge (Figures 9 and 10). The volcanic outcrops detected on the shoal are relative to lava flows and volcanic bodies probably related to a local shallow intrusion, since there are no magnetic evidences of deep roots (Figure 10); ROV images allow us to interpret them as formed in a subaerial environment. Conversely, we do not have any element to infer the provenience of the lava structures occurring on the Fondachello Ridge, since they could be associated to underwater and/or subaerial volcanic manifestations.

Moreover, the ongoing magnetic data processing will provide new information about magnetic susceptibility of crustal bodies identified on the reflection seismic [Firetto Carlino et al. 2016, in this volume] and gravity data [Coltelli et al. 2016, in this volume] acquired within the TOMO-ETNA experiment, strengthening the geological interpretations.

On the whole, the results deriving from this cruise, together with those produced by the other scientific activities of the TOMO-ETNA experiment, will furnish an essential dataset to better constrain the evolution of Etna volcanism and, more in general, the structural pattern offshore the volcano.

Acknowledgements. This work has been partially funded by the MED-SUV project, funding from the European Union's Seventh Program (FP7) under grant agreement No. 308665. We would like to thank the following supporting institutions: Stato Maggiore Marina (Italian Navy General Staff), CINCNAV (Command in Chief of the Fleet), Marisicilia (Navy Command of Sicily) and Coastal Guard of Riposto. We acknowledge Dr. F. Tontini and an anonymous reviewer for their suggestions and comments that have contributed to improving the original version of the manuscript. For his contribution to making the research cruise a success, we thank the Commander Alessio Sabatini of the H/V "Galatea" (Italian Navy) and his crews. We are also grateful to the ROV pilot Daniele Dell'Anna by Subonica and to Fausto Grassa by INGV-Palermo for his help during ROV acquisition. 


\section{References}

Argnani, A., F. Mazzarini, C. Bonazzi, M. Bisson and I. Isola (2013). The deformation offshore of Mount Etna as imaged by multichannel seismic reflection profiles, J. Volcanol. Geotherm. Res., 251, 50-64.

Branca, S., M. Coltelli and G. Groppelli (2011). Geological evolution of a complex basaltic stratovolcano: Mount Etna, Italy, Ital. J. Geosci., 130(3), 306-317.

Caratori Tontini, F., P. Stefanelli, I. Giori, O. Faggioni and C. Carmisciano (2004). The revised aeromagnetic anomaly map of Italy, Annals of Geophysics, 47(5), 1547-1555.

Chiappini, M., A. Meloni, E. Boschi, O. Faggioni, N. Beverini, C. Carmisciano and I. Marson (2000). Shaded relief magnetic anomaly map of Italy and surrounding marine areas, Annali di Geofisica, 43(5), 983-989.

Chiocci, F.L., M. Coltelli, A. Bosman and D. Cavallaro (2011). Continental margin large-scale instability controlling the flank sliding of Etna volcano, Earth Planet. Sci. Lett., 305, 57-64.

Coltelli, M., et al. (2016). The marine activities performed within the TOMO-ETNA experiment, Annals of Geophysics, 59(4), S0428, doi:10.4401/ag-7081.

Corsaro, R.A., M. Neri and M. Pompilio (2002). Paleoenvironmental and volcano-tectonic evolution of the southern flank of Mt. Etna during the last $225 \mathrm{ka}$ inferred from the volcanic succession of the "Timpe", Acireale, Sicily, J. Volcanol. Geotherm. Res., 113, 289-306.

Del Negro, C., and R. Napoli (2002). Ground and marine magnetic surveys of the lower eastern flank of Etna volcano (Italy), J. Volcanol. Geotherm. Res., 114, 357-372.

Faggioni, O., and F. Caratori Tontini (2002). Quantitative evaluation of the time-line reduction performance in high definition marine magnetic surveys, Mar. Geophys. Res., 23, 353-365.

Finlay, C.C., S. Maus, C.D. Beggan, T.N. Bondar, A. Chambodut, T.A. Chernova, A. Chulliat, V.P. Golovkov, B. Hamilton, M. Hamoudi, R. Holme, G. Hulot, W. Kuang, B. Langlais, V. Lesur, F.J. Lowes, H. Luhr, S. Macmillan, M. Mandea, S. McLean, C. Manoj, M. Menvielle, I. Michaelis, N. Olsen, J. Rauberg, M. Rother, T.J. Sabaka, A. Tangborn, L. Toffner-Clausen, E. Thébault, A.W.P. Thomson, I. Wardinski, Z. Wei and T.I. Zvereva (2010). International Geomagnetic Reference Field: the eleventh generation, Geophys. J. Int., 183,1216-1230.

Firetto Carlino, M., F. Zgur, P.P.G. Bruno, M. Coltelli, L. Sormani, D. Cavallaro, J.M. Ibáñez and D. Patanè (2016). Acquisition and preliminary analysis of multi-channel seismic reflection data, acquired during the oceanographic cruises of the TOMO-ETNA experiment, Annals of Geophysics, 59(4), S0430, doi:10.4401/ag-7083.

Fitzgerald, D., A. Reid and P. McInerney (2004). New discrimination techniques for Euler deconvolution, Comput. and Geosci., 30, 461-469.

Ibáñez, J.M., J. Prudencio, A. Díaz-Moreno, D. Patanè, G. Puglisi, B.-G. Lühr, F. Carrión, J.J. Dañobeitia, M. Coltelli, F. Bianco, E. Del Pezzo, T. Dahm, V. Willmott and V. Mazauric (2016a). The TOMO-ETNA experiment: an imaging active campaign at Mt. Etna volcano. Context, main objectives, working-plans and involved research projects, Annals of Geophysics, 59(4), S0426, doi:10.4401/ag-7079.

Ibáñez, J.M., et al. (2016b). TOMO-ETNA experiment at Etna volcano: activities on land, Annals of Geophysics, 59(4), S0427, doi:10.4401/ag-7080.

Lanzafame, G., and J.C. Bousquet (1997). The Maltese escarpment and its extension from Mt. Etna to the Aeolian Islands (Sicily): importance and evolution of a lithosphere discontinuity, Acta Vulcanol., 9, 113120.

Nicolosi, I., F. D’Ajello Caracciolo, S. Branca, G. Ventura and M. Chiappini (2014). Volcanic conduit migration over a basement landslide at Mount Etna (Italy), Sci. Rep., 4, 5293, doi:10.1038/srep05293.

Pareschi, M.T., E. Boschi, F. Mazzarini and M. Favalli (2006). Large submarine landslides offshore Mt. Etna, Geophys. Res. Lett., 33, L13302, doi:10.1029/2006G L026064.

Patanè, G., I. Agostino, S. La Delfa and R. Leonardi (2009). Evolution of volcanism around the eastern sector of Mt. Etna, inland and offshore, in the structural framework of eastern Sicily, Phys. Earth Planet. In., 173, 306-316.

Reid, A.B., L.M. Allsop, H. Granser, A.J. Millet and I.W. Somerton (1990). Magnetic interpretation in three dimensions using Euler deconvolution, Geophysics, 55, 80-91.

Thompson, D.T. (1982). EULDPH: A new technique for making computer-assisted depth estimated from magnetic data, Geophysics, 47, 31-37.

\footnotetext{
${ }^{\star}$ Corresponding author: Danilo Cavallaro, Istituto Nazionale di Geofisica e Vulcanologia, Sezione di Catania, Osservatorio Etneo, Catania, Italy; email: danilo.cavallaro@ingv.it.
}

(C) 2016 by the Istituto Nazionale di Geofisica e Vulcanologia. All rights reserved. 